\title{
4: 82309298-82331904
}

National Cancer Institute

\section{Source}

National Cancer Institute. 4:82309298-82331904. NCI Thesaurus. Code C41791.

Physical location of BMP3_Gene 